\title{
Hizmetkâr Liderlik ve Çalışan Davranışlarındaki Rolü: Kırgızistan’da Bir Alan Araştırması

\author{
(Servant Leadership and Its Role in Employee Behavior: A Field Study in Kyrgyzstan)
}

\section{Kürşad Emrah YILDIRIM iD a}

a Anadolu Üniversitesi, İktisadi ve İdari Bilimler Fakültesi, Çalışma Ekonomisi ve Endüstri İlişkileri Bölümü, Eskişehir, Türkiye. keyildirim@anadolu.edu.tr

\begin{tabular}{|c|c|}
\hline MAKALE BİLGİSİ & ÖZET \\
\hline Anahtar Kelimeler: & \\
\hline $\begin{array}{l}\text { Hizmetkâr Liderlik } \\
\text { Yaratıcılık }\end{array}$ & $\begin{array}{l}\text { üzerindeki etkisini incelemek şeklinde belirlenmiştir. Ayrıca, çalışmada lidere olan güven düzeyinin } \\
\text { de mevcut ilişkilerdeki düzenleyici rolü araştırılmıştır. }\end{array}$ \\
\hline $\begin{array}{l}\text { Örgütsel Vatandaşlık } \\
\text { Davranışı } \\
\text { Lidere Güven }\end{array}$ & $\begin{array}{l}\text { Yöntem - Araştırmanın amacına uygun olarak geçerlilik ve güvenilirliği test edilmiş uygun bir } \\
\text { anket ile tesadüfi örneklem yöntemi kullanılarak Kırgızistan'ın Bişkek şehrinde faaliyet gösteren } \\
\text { tekstil işletmesi çalışanlardan seçilmiş } 378 \text { kişiden veri toplanmıştır. Toplanan veriler uygun } \\
\text { yöntemler ile analiz edilmiştir. }\end{array}$ \\
\hline $\begin{array}{l}\text { Gönderilme Tarihi } 5 \text { Temmuz } \\
2019 \\
\text { Revizyon Tarihi } 16 \text { Eylül } 2019\end{array}$ & $\begin{array}{l}\text { Bulgular - Araştırma bulguları kurulan hipotezleri destekler nitelikte olup, hizmetkâr liderliğin } \\
\text { çalışan yaratıcılığı ve örgütsel vatandaşlık davranışlarını pozitif olarak etkilediği, lidere olan } \\
\text { güvenin de bu ilişkilerde düzenleyici role sahip olduğu tespit edilmiştir. }\end{array}$ \\
\hline $\begin{array}{l}\text { Makale Kategorisi: } \\
\text { Araştırma Makalesi }\end{array}$ & $\begin{array}{l}\text { Tartışma - Elde edilen sonuçlar ile ileride yapılacak çalışmalar için öneriler sunulabilmesi } \\
\text { mümkündür. Farklı ülkelerde veya farklı sektörlerde yapılacak yeni araştırmalardan elde edilecek } \\
\text { sonuçlar ile çalışmanın sonuçları karşılaştırılabilir. }\end{array}$ \\
\hline ARTICLE INFO & ABSTRACT \\
\hline $\begin{array}{l}\text { Keywords: } \\
\text { Servant Leadership } \\
\text { Creativity } \\
\text { Organizational Citizenship } \\
\text { Behavior } \\
\text { Trust in the Leader }\end{array}$ & $\begin{array}{l}\text { Objective - The aim of the study was to investigate the effect of servant leadership on employee } \\
\text { creativity and organizational citizenship behavior. In addition, the role of trust in the leader in the } \\
\text { current relations was investigated. } \\
\text { Method - Data were collected from } 378 \text { selected employees from the textile company operating in } \\
\text { Bishkek city of Kyrgyzstan by using a randomized sampling method and an appropriate } \\
\text { questionnaire which was tested for validity and reliability for the purpose of the study. The collected } \\
\text { data were analyzed by appropriate methods. }\end{array}$ \\
\hline $\begin{array}{l}\text { Received } 5 \text { July } 2019 \\
\text { Revised } 16 \text { September } 2019 \\
\text { Accepted } 20 \text { September } 2019\end{array}$ & $\begin{array}{l}\text { Findings - The findings of the study support the hypotheses established and it has been found that } \\
\text { servant leadership positively affects employee creativity and organizational citizenship behaviors, } \\
\text { and trust in the leader has a regulatory role in these relationships. } \\
\text { Discussion - It is possible to present suggestions for future studies with the results obtained. The } \\
\text { results of the new research in different countries or in different sectors can be compared with the } \\
\text { results of the study. }\end{array}$ \\
\hline
\end{tabular}

\section{GİRIŞ̧}

Küreselleşmeyle birlikte yaşanan hızlı değişimler bilgiye dayalı yaklaşımları ve bilginin önemini daha da gün yüzüne çıkarmaktadır. Bu kapsamda da bilgi devrimine ayak uydurabilen örgütler hızla bilgi yönetimi kapasitesine sahip örgütlere dönüşmektedirler. Bu dönüşüm örgütler açısından son nokta olmamakla birlikte, gelişmişlik düzeyini korumak için gerekli sermaye olan insan sermayesini oluşturmak ve korumak da çok önemlidir. Bu çerçevede, insan kaynağının niteliği ve yakalayabileceği performans boyutları daha da ön plana çıkmaktadır. Çünkü insan kaynağı; bilgisi, tecrübesi ve yetenekleri ile firmalar açısından bilgi yönetim kapasitesinin artırılarak, değer yaratılması adına çok önemli bir girdi sağlamaktadır. Bu nedenle, bireysel düzeyde hakim olunan bilgiyi etkin bir şekilde yöneten organizasyonlar, daha çok değer yaratıp stratejik üstünlük elde edebilecektir. Kısaca, sahip olunan insan kaynağının performansının optimum bir şekilde kullanımı işletmeler açısından büyük önem arz etmektedir. 
Örgütlere sürdürülebilir bir büyüme sağlamak için önemli bir girdi sağlayan bilgiye dayalı bir yönetim için, bu bilgiye sahip olacak olan insan kaynağın; iş hayatındaki verimli ve etkili kullanımı yanında, psikolojik yönden de birçok faktörün etkide bulunabileceği bir unsur olduğu düşünülerek, bu çalışma ile (a) işyerinde çalışanların örgütsel davranış çıtılarının optimum bir şekilde yönetiminin altyapısının oluşturulması; (b) özellikle ülkemizde yeni ele alınmaya başlanan bir kavram olan hizmetkar liderlik ve teorik çerçevesinin kavramsal olarak iyi tanınması, (c) çalışma modelinin gerçek işletme koşullarında test edilmesi, sonuçlarının ortaya konması ve gelecek çalışmalara ışık tutacak değerlendirmeler sunacak olması çalışmanın kapsamını oluşturmaktadır.

Hizmetkâr liderlik ilk olarak 1970 yılında ortaya atılan kavram Greenleaf (2008) tarafından, “Hizmetkâr lider öncelikle hizmetkârdır. Bir kişinin hizmet etmeye istekli olması ve öncelikle hizmet etmesi ile başlar. Arkasından bilinçli bir şekilde liderlik etme arzusu gelir" (s.6) şeklinde tanımlanmıştır. Hizmetkâr liderin genel karakteristik özellikleri arasında çalışanları karar sürecine dâhil etmesi, önemli derecede etik ve önemseyici davranması, çalışanların örgütsel yaşamını önemseyerek ve kalitesini arttırarak gelişmelerini sağlaması şeklinde sıralanmaktadır (Spears, 2010: 25). Dünyadaki değişime paralel olarak önemi giderek artan ve yeni liderlere yol gösterici bir model haline gelen hizmetkâr liderliğin örgütsel ve bireysel çıtılar üzerindeki etkilerinin tespit edilmesi de bu çerçevede önem kazanmaktadır.

Araştırmanın dayandığı temel nokta, örgütsel davranış literatüründe örgütsel algılamalar, tutumlar ve bireysel ya da örgütsel çıktılar kapsamında önemli bir faktör olduğu düşünülen ve bireysel davranışlara temel teşkil eden, günümüzde özellikle yeni yeni kavramsal çerçevesi oluşturulmaya başlayan hizmetkâr liderlik kavramını ele almak, ayrıca bu lider davranışlarının çeşitli çıktılara etkisini inceleyerek literatüre anlamlı kazanımlar sağlamak öncelikli çıkış noktamızdır. Bu kapsamda, bireyin liderlik davranış algıları ve lidere duyduğu güven düzeyi kapsamında örgütsel davranışlardan Örgütsel Vatandaşlık Davranışı ve Bireysel Yaratıcılığın ne düzeyde etkilendiği uygulamalı olarak test edilmiştir. Uygulanan çalışma modelinin henüz literatürde ele alınmayan bir içerikte olması çalışmanın özgün değerine katkı sağlamaktadır. Ayrıca, sahada görev yapan uygulayıcılara da, faaliyetlerinde önemli bir girdi kaynağı olan lider davranışları ve onlara olan güven algısının, bireysel çıktılarında ne düzeyde önemli rol oynadığına yönelik bir bakış açısı sunacak olması da uygulayıcılara yönelik potansiyel etkisi bakımında çalışmanın özgünlüğüne katkı sağlamaktadır.

Son yıllarda artan ilgiye sahip hizmetkâr liderlik davranışlarının da çalışmalarda genellikle örgütsel vatandaşlık davranışı veya lidere güven değişkenleri ile birlikte ele alındığı̆ görülmektedir. Ancak, hizmetkâr liderliğin hem yaratıcılık hem de örgütsel vatandaşlık ilişkilerinde lidere olan güven düzeyinin düzenleyici etkisinin araştırıldığı gözlenmemiştir. Bu çerçevede de çalışmada hizmetkâr liderliğin çalışan yaratıcılığı ve örgütsel vatandaşlık davranışı üzerindeki etkisi, lidere güven algısının aracı olduğu durumlarda değerlendirilecektir.

\section{KAVRAMSAL ÇERÇEVE}

\subsection{Hizmetkâr Liderlik}

Günümüz dinamik iş dünyasında, statükoya meydan okumak, örgüt üyelerine ilham vermek ve onları ikna ederek etkileyebilmek için liderlere ihtiyaç bulunmaktadır. Liderlik, ilkel toplumlardan günümüz modern toplumlarına kadar geçen sürede insanoğlunun ihtiyaçlarının doğal bir sonucu olarak ortaya çıkan bir kavramdır. Sosyal bir varlık olan insanın çevresiyle ve diğer bireylerle sürekli etkileşimi, toplumsal yaşamı ve toplumsal ilişkileri meydana getirmiştir. Toplumsal yaşama geçişle birlikte belirli gruplar içinde yaşama, bu grupların içerisinde örgütlenme ve ortak amaçlar doğrultusunda hareket etme söz konusu olmuştur. Bu noktada da bireylerin çeşitli hedefler doğrultusunda yönlendirilmesi ve bu hedeflere doğru hareket ettirilmesi ihtiyacı ortaya çıkmıştır (Akdoğan ve Demirtaş, 2014). Gerek iş hayatı gerekse sosyal hayatımızda insanın faaliyet gösterdiği tüm durumlarda liderlik kavramı sıkça karşımıza çıkmaktadır. İnsanlar genel olarak herhangi bir yönlendirme olmadan eylem gösterme konusunda pek aktif olmadıklarından liderliğin önemli bir fonksiyonu yerine getirdiği değerlendirilmektedir.

Liderlik genel olarak süreç ve özellik bakımından tarif edilmektedir. Süreç açısından liderlik; örgüt üyelerinin etkinliklerini, çalışmalarını örgüt hedefleri doğrultusunda yön göstererek, tanzim eden kişi olarak nitelendirilirken, özellik teorisi açısından liderlik ise, grup üyelerine başarılı bir şekilde tesir edecek karakteristik özelliklere sahip olunmasını vurgulamaktadır (Özkalp ve Kırel, 2004). Bir diğer tanıma göre 


\section{K. E. Yildirım 11/3 (2019) 2242-2256}

liderlik, belirli amaç etrafında bir grup insanı bir araya getirebilme ve bu amaçları gerçekleştirmek için onları eyleme geçirme bilgi ve yeteneklerinin toplamı olarak ifade edilmektedir (Eren, 2003).

Davranışsal, özellikler ve durumsal yaklaşımlar değerlendirilerek bir tanımlama yapmak gerekirse lider, bir grup insanı kendi vizyonlarını takip etmek ve gerçekleştirmek üzere etkileyen, yönlendiren ve ilham veren, sonuçta da takipçilerini ortak ideallere ulaştırabilen kişidir. Görüleceği üzere tanımın ilk bölümü biraz daha bireyci olup, birey ve onun vizyonu daha ön plandadır. Çünkü insanlar öncelikle kendi bireysel amaç ve hedeflerine ulaşmak isterler. İkinci kısımda ise bireysel vizyonla ortak hedeflere yönelme söz konusudur. Bu kapsamda liderler takipçileri olan grup üyelerini etkilerken bireysel ve örgütsel amaçların uyumuna ve entegresine odaklanmalı, süreçte de onları kendi vizyonlarına ulaşmalarında eğitmeli ve yetiştirmelidirler.

Pozitif örgütsel davranışların, örgütlerin performansları üzerindeki olumlu etkisi günümüzde bilinen bir gerçektir ve çalışanların pozitif örgütsel davranışlar göstermelerini sağlayabilecek öncüllerin neler olduğu örgütsel davranışın en önemli araştırma konusudur. Liderlik, çalışanların yüksek performans göstermeleri ve örgüt amaçlarına mümkün olan en üst düzeyde katkı yapabilmeleri ve örgüte zarar verici davranışların azaltılması (Demirtaş ve Biçkes, 2014) konusunda kritik öneme sahiptir. Zaman değiştikçe liderlik davranışları ile ilgili görüssler de değişmekte, beklentiler farklılaşmaktadır. Günümüzde organizasyonlarda daha insan odaklı ve daha hizmet odaklı bir liderlik anlayışına ihtiyaç duyulmaktadır. Bu nedenle de hizmetkâr liderlik organizasyonların mevcut ihtiyaçlarını karşılayan liderlik modeli haline gelmiştir (Van Dierendonck, 2010: 1228). Hizmetkâr liderlik uzun yıllardan beri bilinen bir liderlik yaklaşımı olmakla beraber, son yıllarda hem akademik anlamda hem de uygulamada daha da fazla araştırmaya konu olmaya başlamış bir liderlik yaklaşımıdır.

Bir kavram olarak Hizmetkâr Liderlik 1970 yılında ilk olarak Robert K. Greenleaf tarafından kullanılmıştır. Greenleaf'ın büyük kurumlardaki çalı̧̧maları sonucunda biriktirdiği deneyimler Hizmetkâr liderlik düşüncesine zemin hazırlamıştır (Spears, 1996). Hizmetkâr liderlik, yöneten konumundaki kişilerin rollerinde ciddi değişiklikleri beraberinde getiren yeni nesil bir liderlik modelidir. Hizmetkârlık felsefesi ile liderin rollerini birleştirip tek bir rol haline getiren Greenleaf, her bir liderin aslında bir izleyici olduğun da altını çizmektedir. Benzer şekilde yazar, hizmetkârlık rolünü liderlik rolünün karşısında daha önemli olarak ele almaktadır. Bu sebeple, hizmetkâr liderlik davranışlarında hizmet anlayışı daha ön planda durmaktadır. Hizmetkâr rolünde olan liderlerin hizmet etmeye ilişkin tutum ve davranışları içten gelen ve bu hizmetler sayesinde keyif almayı sağlayan bir uğraş olarak ele alınmaktadır (Greenleaf, 1977).

Hizmetkâr liderler takipçilerini başarıya ulaştırmak için neye ihtiyaçları olduğunu bulmaya çalışırlar. Takipçilerinin kendisini memnun etmesini beklemekten ziyade, onların hayatlarında bir fark yaratma çabası içinde davranışlar sergilemektedirler (Vinod ve Sudhakar, 2011). Bu tür liderler devamlı olarak hareket ettikleri topluluğun başarılı olmaları adına onların nelere gereksinimi olduklarını araştırır ve lideri olduğu topluluğun hayatlarında nüanslar yaratmaya çalışarak örgütsel başarıyı hedeflerler. Örgütün ilerlemesi için hizmet ederlerken, çalışanların ellerinden gelenin en iyisini yapması için onları ilham veren bir özendirme ile amaçlarına yönlendirirler. Hizmetkâr liderlik bu anlamda bir liderlik üslubu olduğu kadar liderin mesuliyetlerine karşı geliştirilen davranış biçimi şeklinde de ele alınmaktadır (Page ve Wong, 2000). Patterson (2003), hizmetkâr liderlerin vasıflarını erdem ve yüksek ahlaki özelliklere sahip, iyi olmaya dair uğraş içinde olan, dürüst bir kişilik olarak sıralamakta ve takipçilerinin ilgi ve ihtiyaçlarını merkeze alan, örgütü onlar için bir hayat alanı olarak gören kişiler olarak tanımlamıştır. Hizmetkâr liderler iletişime oldukça önem veren liderler olarak takipçileri ile sıkı bir iletişim ağı oluştururlar. Ayrıca, farkındalık yetenekleri yüksek bireyler olarak duygusal iyileştirme yetenekleri ve duygu yönetim kabiliyetleriyle de kendilerini, takipçilerini ve örgütü sürekli olarak zinde tutarlar (Spears, 1995).

Hizmetkar liderliğin önemli özellikleri arasında bu tür liderlerin nihai amacının yalnızca örgütün amaçlarını gerçekleştirmek değil, aynı zamanda diğer paydaşların ve toplulukların çıarlarını da gözetmek olduğu ifade edilmektedir (Walumbwa et al., 2010). Liden vd. (2008) bu özelliklerini doğrulayarak hizmetkâr liderlik davranışlarını ölçmek için bazı anahtar boyutlar belirlemişlerdir. Bu boyutlar; takipçileri öncelikli ele alarak onları güçlendirmek, gelişme ve başarılarına katkı sağlamak, etik olmak, kavramsal beceriler sunmak ve topluluk için değer yaratmak şeklinde vurgulanmışır. Bu özellikler ve davranışlar, hizmetkar liderin, bir hizmet politikası dikte etmek yerine örnek davranışlarla organizasyonu yönetmesini sağlamaktadır (Ehrhart, 2004). 


\section{2. Örgütsel Vatandaşlık Davranışı}

İlk olarak 1983 yılında kavramsal olarak ortaya konmuş olan örgütsel vatandaşlık davranışı (Bateman ve Organ, 1983; Van Dyne vd., 1994), bireyin örgütsel faaliyetlerinde kendisine belirlenen sınırların ve iş tanımının dışına çıkarak, fazladan gönüllü olarak rol davranışlarında bulunması ve bireyin çalışma ortamındaki fazladan çaba sergileme isteği olarak tanımlanmıştır (Organ, 1988). Örgütsel amaçların gerçekleşmesine yardımcı olan davranışları ifade eden bu kavram gönüllülük esaslı olup, örgütün sosyal ve psikolojik ortamlarına da katkıda bulunmaktadır (Lievens ve Anseel, 2004).

Örgüt içerisinde birlikte çalıştıkları arkadaşlarına yardımcı olma, iş faaliyetlerinin gelişimi ve süreci hakkında diğerlerine yardım etme ve yeni stratejiler geliştirerek örgüte fayda sağlama, çalışma saatlerine özen gösterme ve zamanı etkili değerlendirme gibi bir takım davranışlar örgütsel vatandaşlık davranışları içerinde yer almaktadır. (Organ, 1988). Kişinin içten duygularla ve gönüllü olarak yaptığı davranışların altında herhangi bir dişsal mükafat beklentisi söz konusu değildir. Örneğin, kendisinden herhangi bir spesifik beklenti olmamasına rağmen, iş çıkışında uzun süre ofisinde çalışmaya devam ederek elindeki işi bitirmek için çalışan birisi ya da kendi resmi işinin bir parçası olmadığı halde, işini yapmakta zorlanan bir çalışma arkadaşına yardımda bulunan bir çalışanın davranışları örgütsel vatandaşlık davranışlarının birer göstergesidir (Podsakoff vd., 2009).

Örgütsel Vatandaşlık Davranışı, örgütün biçimsel ödüllendirme sistemi tarafından değerlendirilmeyen, çalışanların gönüllülük esasına dayalı olarak yaptıkları ve sonunda örgütün başarısına olumlu katkı sağlayan davranışlar (Organ, 1988) olarak, öncülleri uzun zamandır araştırma konusu olarak birçok çalışmanın temel değişkenini oluşturmaktadır. Örgütsel vatandaşlık davranışına ait birçok farklı boyuttan söz edilmekle birlikte genel olarak Organ'ın beş boyutlu örgütsel vatandaşlık davranışı boyutları kabul görmektedir. Bu boyutlar sırasıyla, fedakarlık/özgecilik (Altruism), sorumluluk (Conscientiousness), sivil erdem (civic virtue), centilmenlik (Sportsmanship) ve nezaket (Courtesy) olarak sıralanmıştır (Podsakoff et al., 2009; Podsakoff et al., 2000).

Örgütsel vatandaşlık davranışına neden olan eylemlerin iki ayrı boyutu vurgulanmaktadır. Bunlardan birincisi bilişsel boyut diğeri ise duyuşsal boyuttur. Yani bir örgüt içerisinde yer alan çalışanların içinde bulunduğu bilişsel ve duyuşsal özellikler örgütsel vatandaşlık davranışlarının gerçekleşmesi açısından önemli derecede rol oynamaktadır (Penner vd., 1997). Örgütsel vatandaşlık davranışına tesir eden esas etkenlerden bir diğeri de yöneticilerin sergiledikleri liderlik biçimidir. Özellikle, bir çalışan ile lideri arasındaki güven ve çalışma hayatına yönelik ilham veren özendirme sergilenen bir yönetim biçimi, örgütsel vatandaşlık davranışların daha çok ortaya konmasını sağlamaktadır. Bu nedenle, çalışanlardan asgari beklentilerin ötesine gitmelerini isteyen örgütlerin, lider ve takipçileri arasında karşılıklı güven oluşturan yüksek nitelikli işlere yönlendiren bir çalışma ortamı ve örgüt kültürü oluşturmaları faydalı çıtılar ortaya koyacaktır (Gibson vd., 2003).

Literatür sonuçları, örgütsel vatandaşlık davranışı gibi çalışanların farklı tutum ve davranışlarının örgütsel başarıya ulaşmada önemli birer girdi sağladığını ortaya koymaktadır (Farh, Zhong, \& Organ, 2004; Paine \& Organ 2000; Podsakoff, Ahearna, \& MacKenzie, 1997; Podsakoff \& MacKenzie, 1997; Podsakoff, Whiting, Podsakoff, \& Blume, 2009). Bu kapsamda birçok bulgu örgütsel vatandaşlık davranışlarının bireysel ve örgütsel performansı olumlu yönde etkilediğini ifade etmiştir (Organ \& Ryan, 1995; Podsakoff et al., 2009; Podsakoff et al., 2000). Literatür değerlendirmeleri hizmetkâr liderliğin örgütsel vatandaşlık davranışının bir öncülü olduğunu vurgulamaktadır (Ehrhart, 2004; Luu, 2019; Amah, 2018; Walumbwa vd., 2010; Vondey, 2010). Bu altyapı kapsamında ifade edebileceğimiz husus; hizmetler liderliğin, pozitif örgütsel çıtıların en önemlilerinden birisi olan örgütsel vatandaşlık davranışı üzerinde anlamlı düzeyde pozitif bir etkide bulunacağıdır.

\section{3. Çalışan Yaratıcılığı}

Yaratıcılık, orijinal ve işe yarar fikirlerin üretilmesi anlamında olup örgütsel çalışmalarda dikkatleri giderek üzerine çekmektedir (Gong vd., 2013). Organizasyonlarda verimliliğin artırılabilmesi için çalışanların yeteneklerini, becerilerini, yaratıcılıklarını ve bilgilerini özgürce kullanabilmeleri gerekmektedir (Reinke, 2004). Yaratıcılık, rekabet avantajının kaynağı olan sürdürülebilir yenilik için önemli olmakla beraber son 
zamanlarda büyüyen küresel stratejinin bir sonucu olarak yönetim alanına girmiştir (Bissola ve Imperatori, 2011).

Yaratıcılığın giderek önem kazanmasının temel nedeni örgütlerin yeniliğe duydukları ihtiyacın artması ve yeniliğin de ancak çalışanların yaratıcılığı ile mümkün olması şeklinde ifade etmek mümkündür. Bireysel yaratıcılık, örgütsel yeniliğin tuğla taşı olarak değerlendirilmektedir (Tierney vd., 1999). Rawlinson (2017), her insanda yaratıcılık yeteneğinin az ya da çok olduğunu, ancak bazı bireylerde dış etmenlerle yaratıcı yeteneklerin başka bir takım yeteneklerin altında örtülü kalmaya zorlandığını söylemektedir. Sungur (1997) da, yaratıcı olmayan birey olmadığını; sadece az ya da çok engellenmiş, dondurulmuş ve uzun ya da kısa süreli eğitime ihtiyacı olan bireyler olduğunu belirtmektedir.

Yaratıcılık liderlik tarzından etkilenen bir davranıştır. Bir liderin takipçilere yönelik yönelimleri ve eylemleri, yaratıcı davranışlar oluşturabilir veya engelleyebilir (Shalley ve Gilson, 2004). Gelişmeleri keşfetme zihniyetine sahip liderler problemleri çözmek için çeşitli yaklaşımları kullanarak, gelişme ve öğrenmeyi teşvik ederek yaratıcılığın öğrenilip geliştirilmesi konusunda çalışanlara örnek teşkil ederler (Ehrhart, 2004; Neubert vd., 2008). Her örgütte örgütsel ortam ve koşullar elverişli olduğu müddetçe orijinal ve değişime meraklı, açık fikirli, araştırmadan bıkmayan, ısrarcı, sorun çözmeye odaklanmış, yeni fikirlere açık, arzulanan yaratıcılığı gerçekleştirecek çalışanlarlar olabilir. Önemli olan onlara cesaret vererek yaratıcılığı ortaya çıkaracak ve buna uygun çalışma ortamı hazırlayacak yöneticilerin olup olmamasıdır. Jung vd. (2003) çalışanlarının yaratıcı çabalarını teşvik ederek, yaratıcı şekilde çalışmalarını sürdürmelerine imkân veren ve yeni beceri gerektiren çabalarına içsel ve dışsal olarak ödül veren organizasyonların, sürdürülebilir olacaklarını ileri sürmüşlerdir.

Sosyal değişim teorisine göre çalışanlar çevrelerine nasıl davranacaklarına liderlerini gözlemleyerek ve liderlerin kendilerine olan davranışlarını kendi işlerine uyarlayarak karar verirler (Bandura, 1986). Hizmetkâr liderlerin yaratıcılığ 1 arttırma yollarından biri takipçilerin içsel motivasyonunu ve psikolojik güvenliğini arttırmaktır. Motive olmuş bir çalışanın yaratıcılık kabiliyeti yüksektir çünkü risk almaya ve engellerle yüzleşmeye hazırdırlar. Liderin fazla kontrolcü ve yönlendirici olması motivasyonu, dolayısıyla yaratıcılı̆̆ı düşürebilir. Buna karşın merak uyandıran ve izleyicinin gelişimini takip eden katılımcı hizmetkar liderler takipçilerin yaratıcılığını canlandıracak içsel motivasyonu arttırabilmektedirler (Oldham ve Cummings, 1996).

Yaratıcılığın bir başka öncülü ceza veya suçlanma tehdidi olmaksızın çalışanların yeni fikirler üretmek konusunda risk alma özgürlüğ̈̈ hissettikleri güvenlik duygusudur (Shalley ve Gilson, 2004). Çalışanlarının çıkarlarını önemseyen liderler onların yaratıcılık için sahip oldukları öz-yeterliliğe katkıda bulunur ve yeni yollar keşfetmek, başarısızlıklardan ders çıkarmak ve fikirlerini liderlerle paylaşmak için kendilerini güvende hissettikleri destekleyici bir çalışma ortamı yaratırlar (Hirak vd., 2012; Shalley ve Gilson, 2004).

Çalışanların yaratıcı davranışlarının liderlik davranışları ile olan ilişkisine yönelik çeşitli çalışmalar yapılmıştır (Neubert vd., 2016; Zhang ve Bartol, 2010; Gupta vd., 2012; Wang vd., 2013). Örneğin Neubert vd.'nin (2016) 9 hastaneden; 1485 hemşire ve 105 hemşire yöneticisi ile yaptıkları araştırmada hizmetkâr liderliğin çalışan yaratıcılığı üzerinde pozitif etkisi olduğunu tespit etmişlerdir. Literatür değerlendirmelerinde hizmetkar liderliğin takipçilerin davranışlarını etkilediğini gösteren bulgular olmasına karşın, hizmetkar liderlik ve çalışanların yaratıcı davranışları arasındaki ilişkiyi belirlemeye yönelik pek fazla araştırmaya rastlanmamıştır.

Literatür bulguları hizmetkâr liderlerin organizasyonda güven ortamı yaratarak yaratıcıllı̆̆ı ve girişimciliği harekete geçireceğini ifade etmektedir (Reinke, 2004). Hizmetkar liderliğin çalışan yaratıcılı̆̆ üzerindeki pozitif etkisini kanıtlayan sınırlı sayıdaki çalışmalardan (Williams vd., 2017; Yang vd. 2017; Yang vd., 2019) ve organizasyondaki bireysel davranışların, bireylerin belirli bir şekilde davranması için yükümlülükler yaratan bir dizi etkileşimden oluşan sosyal paylaşımdan kaynaklandığını öne süren sosyal değişim teorisinden (Blau, 1964) hareketle, hizmetkâr liderlik ile çalışanın yaratıcı davranışı arasındaki ilişkiyi araştırmak çalışmanın amaçlarından birisi olmuştur.

\subsection{Düzenleyici (Moderator): Lidere olan Güven}

Modern zamanda örgütlerin yaşamlarını devam ettirerek gelişmesi için gerekli bir kavram olan güven, birbirinden değişik bakış açıları ile tanımlanmıştır. Güven, en basit tanımı ile karşılıklı ilişki içerisinde olduğumuz bireylerin, kendilerinden beklediğimiz şekilde davranacaklarına veya olumlu anlamda beklentilerimizi karşılayacaklarına dair duyduğumuz inançtır (Shaw, 1997). Bir başka tanıma göre güven; 


\section{K. E. Yildırım 11/3 (2019) 2242-2256}

bireyin başka bir bireye karşı, o bireyin davranışlarını kontrol etme gücü olmaksızın kendini savunmasız bırakmasıdır (Rousseau vd., 1998). Robbins ve Judge (2001) güveni, karşı tarafın sözlerinde, davranışlarında ve kararlarında çıkarcı ve bencil bir tarzda davranmayacağı konusunda olumlu beklenti ve inanç içinde olmak şeklinde tanımlamaktadır.

Güven ile ilgili araştırmalarda, alt boyutların üç ayrı düzeyde incelendiği görülmektedir. Bunlar; yöneticiye duyulan güven, kuruma duyulan güven ve çalışanlar arası güvendir (Shaw, 1997). Bu çalışmada güven, "lidere güven" boyutuyla araştırmaya dahil edilmiştir. Karşı tarafın davranışlarını tahmin etme ve etkileme yeteneği ile ilgili olan lidere güven (Borgen, 2001) liderin faaliyetlerinin önemli sonuçlar ortaya koyacağı inancıyla bireylerin duyarlı davranması olarak tanımlanmıştır (Mayer vd., 2008). Bir başka tanımlamada "lidere duyulan güven", liderin takipçileri ile ilgili doğrudan kontrol altında tutamadığı ve onları etkileyecek davranış ve kararlarında takipçilerine zarar vermeyeceği ve onları gözeteceği konusunda oluşan pozitif beklenti olarak tanımlanmıştır (Tan ve Tan, 2000).

Yöneticiye güvenmek için mutlaka onu beğenmek veya onunla aynı fikirde olmak gerekmez. Güven, liderin söylediğini gerçekten kastettiğine duyulan inançtır. Yani onun otantik davranışlar sergilediğine yönelik inançlarıdır. Liderin davranışları ile açıkladığı ifadeler birbirleriyle tutarlı veya en azından uyumlu olmak zorundadır (Özdaşlı ve Yücel, 2010: 68). İnsanlar liderlerin kişisel bütünlüklerini örgütsel sadakate dönüştürdüğünü görünce güven duyguları artmaktadır. Çalışanlar, liderini örgütün bir temsilcisi olarak görerek ona güvendiği zaman, bu güvenin kapsamını genelleştirerek tüm örgüte yayabilirler (Mayer vd., 2008).

Literatür araştırmaları da liderlik davranışı ve güven arasındaki önemli bağlantıya dikkat çekmiştir (Brower vd., 2000; Arnold vd., 2001; Dirks ve Ferrin, 2002; Joseph ve Winston, 2005). Takipçilerin lidere güven duymasında liderlik tarzının ve lider davranışlarının önemi oldukça büyüktür. Liderlerin davranışları takipçilerin güven düzeyini belirleyen önemli bir faktördür (Joseph ve Winston, 2005). Liderler davranışlarıla güven yaratırlar ve sürdürürler. Davranış bu nedenle liderlere olan genel güven algılarını değerlendirmek ve harekete geçirmek için bir araçtır (Bennis, 2002; De Pree, 2002). Güven öncelikle liderin iletişimsel ve destekleyici davranışlarının ürünü olarak kabul edilmektedir. Liderlik literatüründeki değerlendirmeler, iyi liderlerin temel değerlerini dürüstlük ve doğruluk şeklinde ifade etmiş ve bu değerlerin bireysel ve örgütsel güveni inşa etmede önemli bir rol oynadıklarını vurgulamışlardır (Posner ve Kouzes, 1993).

Güven diğer liderlik tiplerinde olduğu gibi hizmetkâr liderlikte de önemli bir unsurdur (Wilkes, 2011). Güven ve hizmet üzerine kurulan ilişkiler, hizmetkâr liderliğin etkisinin temelini oluşturmaktadır (Sarkus, 1996). Greenleaf (1977), güvenin hizmetkâr liderler için bir yapı taşı olduğunu ve bunun da güven ortamını teşvik ettiğini ileri sürmüştür. Joseph ve Winston (2005), Amerika ve Batı Hint Adaları'ndaki kar amacı güden ve gütmeyen organizasyonlardaki liderler üzerinde yaptıkları çalışmada, hizmetkâr liderlik ve lidere güven arasında pozitif bir ilişki olduğunu ifade etmişlerdir. Ayrıca, Russell ve Stone (2002) tarafından yapılan diğer bir çalışmada da hizmetkâr liderlik modelinde güven, hizmetkâr liderliğin işlevsel özelliklerinden biri olarak ele alınmıştır.

Walumbwa vd., (2010) hizmetkar liderliğin örgütsel vatandaşlık davranışını farklı mekanizmalarla etkilediğini belirlemiş ve bu mekanizmaların diğer çalışmalarla ilave araştırılması gerektiğini ifade etmişlerdir. Bu kapsamda, lidere olan güven mekanizması da bu mekanizmalardan birisi olarak mevcut çalışma modelinde ele alınmıştır. Benzer şekilde Reinke (2004: 37)'de hizmetkâr liderlerin güven ortamı yaratacak örgütte yaratıcılığı artıracağını belirtmiştir.

Greenleaf (1998), sosyal değişim teorisiyle bütünleştirerek hizmetkâr liderlerin takipçilerinin güvenini kazanarak üstün performans göstermeleri konusunda onları motive edeceklerini ifade etmiştir. Jaiswal ve Dhar (2017) Hindistan'daki 26 işletmede, 800 çalışan ve 800 denetçiye uyguladıkları araştırmada, hizmetkâr liderlik ile çalışan yaratıcılığı arasında pozitif ilişki olduğunu ve lidere olan güvenin de bu ilişkiye aracılık ettiğini tespit etmişlerdir. Yapılan araştırmalar ve Greenleaf'ın (1998) teorisinden hareketle bu çalışmada hizmetkâr lider davranışları ile çalışan yaratıcılığı ve ilave olarak hizmetkâr lider davranışı ile örgütsel vatandaşlık davranışı arasındaki ilişkide lidere olan güvenin aracı olacağı yönünde varsayımlar oluşturulmuştur. 


\section{YÖNTEM}

Çalışma kapsamında öne sürülen hipotezlerin test edilmesi amacıyla kullanılan veriler, firmaların tam zamanlı çalışanlarından, yüz-yüze görüşme ile anket uygulaması yapılarak elde edilmiştir. Çalışanlardan; hizmetkar liderlik davranışları, örgütsel vatandaşlık davranışı, yaratıcılık ve lidere güven algılamalarını ölçen değerlendirme formlarını doldurmaları istenmiştir.

Çalışmanın veri toplama aşamasında kullanılan ölçekler, bugüne kadar geçerlilik ve güvenilirliği onaylanmış ölçeklerden seçilmiş, örneklem grubuna cevapların tamamen gizli tutulacağı ve hiçbir şekilde açıklanmayacağı yüz-yüze yapılan görüşmelerde ifade edilmiştir. Ayrıca, ortak yöntem sapmasının Podsakoff vd. (2012) tarafından da önerildiği şekliyle hizmetkâr liderlik davranışları ile ilgili maddeler, bağımsız değişkenlerden önce gelecek şekilde düzenlenmiştir.

\section{1. Örneklem}

Araştırmanın evrenini Kırgızistan'ın Bişkek şehrinde faaliyet gösteren tekstil işletmelerin çalışanları oluşturmaktadır. Bişkek'te farklı tekstil kuruluşlarında çalışan 500 kişi kolayda örneklem yöntemi ile seçilmiş ve bu kişilere anket uygulanmıştır. Uygulama esnasında eksik veri ve yanlış kodlamalar nedeniyle 378 (n) adet anket değerlendirmeye tabi tutulmuştur. Ayrıca, çalışmada kaynaklarımız ve örneklemin büyümesinden kaynaklanan fayda-maliyeti düşünerek amaç olarak diğer sosyal araştırmalarda olduğu gibi yüzde 5'lik bir standart hata düzeyi amaçlanmıştır. Anketler incelendiğinde analize tabi tutulan 378 anket için standart hata düzeyi Kish, (1980) tarafından önerilen sınırlarda yer almıştır.

Örneklem grubunun demografik özellikleri incelendiğinde erkeklerin \%61.2, kadınların da \%38.8 oranında olduğu, eğitim durumlarının \%51.4 ile daha çok lise veya dengi seviyede okullardan olduğu, aylık gelir durumlarının 25.000-30.000 Kırgız Somu (1 Som=0.076 Türk Lirası) arası seviyelerde (\%68.3) olduğu gözlenmiştir.

\section{2. Ölçekler}

Hizmetkâr Liderlik Davranışlarının, ölçümü için Liden vd. (2008) tarafından geliştirilen 28 ifade içeren Hizmetkâr Liderlik Ölçeği kullanılmıştır. Ölçekte 1= Kesinlikle Katılmıyorum, 5= Kesinlikle Katılıyorum'u ifade etmektedir. Bu ölçekte "Yöneticim kendi başarısından öte benim başarım için çaba sarf eder" gibi örnek bir ifade kullanılmıştır. Ölçekteki yüksek puanlı sorular hizmetkâr liderlik davranışlarının yüksek oranda olduğunu ifade etmektedir. Ölçeğin güvenilirliğinin testine yönelik yapılan analizde Cronbach's Alfa değeri 0.83 olarak tespit edilmiştir.

Lidere Güven Algısının, ölçümü için Podsakoff vd. (1990) tarafından geliştirilen 8 ifade içeren Lidere Güven Ölçeği kullanılmıştır. Ölçekte 1= Kesinlikle Katılmıyorum, 5=Kesinlikle Katılıyorum'u ifade etmektedir. Bu ölçekte "Yöneticimin bana her zaman dürüstçe davranmaya çalıştığına eminim" gibi örnek bir ifade kullanılmıştır. Ölçekteki yüksek puanlı sorular lidere güven algısının yüksek oranda olduğunu ifade etmektedir. Ölçeğin güvenilirliğinin testine yönelik yapılan analizde Cronbach's Alfa değeri 0.77 olarak tespit edilmiştir.

Örgütsel Vatandaşlık Davranışlarının, ölçümü için Podsakoff vd. (1990) tarafından geliştirilen ve 5 alt boyutta 24 ifade içeren bir ölçek kullanılmıştır. Ölçekte 1= Kesinlikle Katılmıyorum, 5= Kesinlikle Katılıyorum'u ifade etmektedir. Bu ölçekte "İş esnasında zorluklarla karşılaşan arkadaşlarıma yardım etmekten kaçınmam” gibi örnek bir ifade kullanılmıştır. Ölçekteki yüksek puanlı sorular OCB seviyesinin yüksek oranda olduğunu ifade etmektedir. Ölçek alt boyutlarının ortalaması üzerinden yapılan güvenilirlik sonuçlarında Cronbach's Alfa değeri 0.84 olarak tespit edilmiştir.

Çalışan Yaratıcılığının ölçümü için Hurt vd. (1977) tarafından geliştirilen ve 20 ifade içeren Bireysel Yaratıcılık II ölçeği kullanılmıştır. Ölçekte 1= Kesinlikle Katılmıyorum, 5= Kesinlikle Katılıyorum'u ifade etmektedir. Bu ölçekte "Yeni düşüncelere açık biriyim" gibi örnek bir ifade kullanılmıştır. Ölçekteki yüksek puanlı sorular yaratıcılık seviyesinin yüksek oranda olduğunu ifade etmektedir. Ölçeğin güvenilirliğinin testine yönelik yapılan analizde Cronbach's Alfa değeri 0.91 olarak tespit edilmiştir.

\subsection{Araştırmanın Modeli ve Hipotezler}


Araştırmanın amaçları dikkate alınarak geliştirilen araştırma modeli Şekil 2'de verilmiştir.

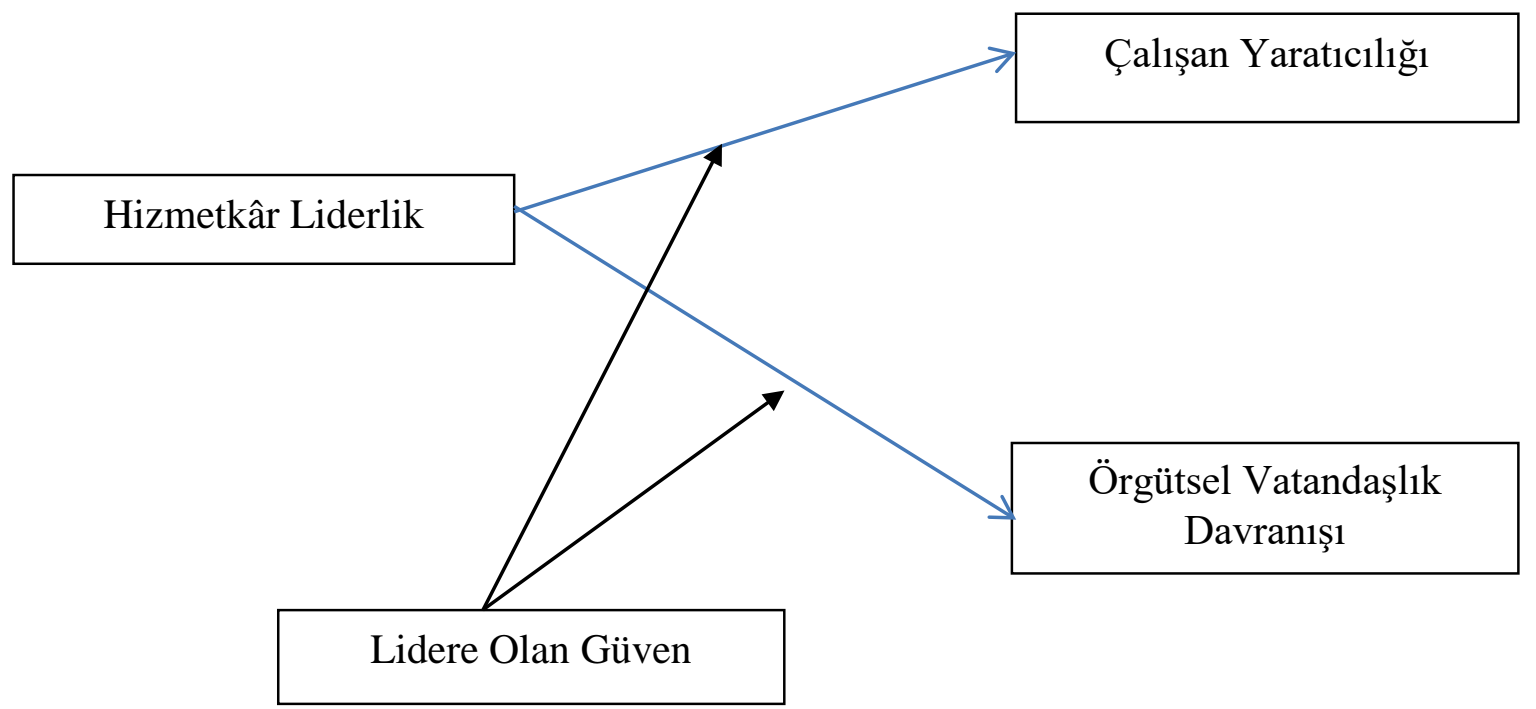

Şekil 2. Araştırmanın Modeli

Çalışmanın hipotezleri ise şu şekilde oluşturulmuştur;

Hipotez 1: Hizmetkâr liderlik davranışları çalışanların örgütsel vatandaşlık davranışlarını pozitif olarak etkilemektedir.

Hipotez 2: Hizmetkâr liderlik davranışları çalışanların yaratıcılığını pozitif olarak etkilemektedir.

Hipotez 3a: Lidere olan güven hizmetkâr liderlik davranışları ve örgütsel vatandaşlık davranışları ilişkisinde düzenleyici role sahiptir. Bu ilişkide yüksek seviye lidere güven ilişkinin kuvvetini artıracaktır.

Hipotez 3b: Lidere olan güven hizmetkâr liderlik davranışları ve çalışanların yaratıcıllı̆̆ ilişkisinde düzenleyici role sahiptir. Bu ilişkide yüksek seviye lidere güven ilişkinin kuvvetini artıracaktır.

\section{Bulgular}

Çalışmanın bu bölümünde, katılımcılardan toplanan bilgilerin analizi sonucu elde edilen bulgulara yer verilmiştir. İlk olarak değişkenlerine ait korelâsyonlar, ortalama ve standart sapmalar Tablo 1'de sunulmuştur.

Tablo 1. Değişkenlere İlişkin Korelasyonlar, Aritmetik Ortalamalar ve Standart Sapmalar

\begin{tabular}{lcccccc}
\hline Değişkenler & Ort. & $\begin{array}{c}\text { Std. } \\
\text { Sapma }\end{array}$ & $\mathbf{1}$ & $\mathbf{2}$ & $\mathbf{3}$ & $\mathbf{4}$ \\
\hline Hizmetkâr Liderlik & 3.30 & 0.96 & - & & \\
\hline Lidere Güven & 3.77 & 1.13 & $0.298^{* *}$ & - & \\
\hline Örgütsel Vatandaşlık Davranışları & 3.97 & 1.06 & $0.307^{* *}$ & $0.514^{* *}$ & - \\
\hline Çalışan Yaratıcılığı & 3.56 & 1.09 & $0.312^{* *}$ & $0.408^{* *}$ & $0.507^{* *}$ & - \\
\hline
\end{tabular}

Not: ${ }^{* *} \mathrm{p}<0,01$ ve (Çift Yönlü)

Tablo değerleri incelendiğinde tüm değişkenler itibariyle anlamlı korelasyonların olduğu tespit edilmiştir. İlave olarak çalışma hipotezlerini değerlendirmek üzere hiyerarşik regresyon analizleri yapılarak aşağıdaki Tablo-2 ve Tablo-3'deki sonuçlar elde edilmiştir. Hiyerarşik regresyon analizlerinde çoklu eş bağımlılık 
K. E. Yildırım 11/3 (2019) 2242-2256

(multicollinearity) sorununu çözmek için Aiken ve West (1991) tarafından önerilen yöntem kullanılmıştır. Bu kapsamda öncelikle değişkenlere ait merkezileştirme işlemleri gerçekleştirilmiştir. Ardından hiyerarşik regresyon analizleri uygulanarak veriler elde edilmiştir.

Tablo 2. Lidere Güvenin Hizmetkâr Liderlik ve Örgütsel Vatandaşlık Davranışları İlişkisindeki Düzenleyici Rolü

\begin{tabular}{|c|c|c|c|c|c|}
\hline & $\begin{array}{c}\text { OVD } \\
(\boldsymbol{\beta})\end{array}$ & Düzeltilmiş $\mathrm{R}^{2}$ & $\Delta R^{2}$ & F Değişimi & $\begin{array}{l}\text { Durbin- } \\
\text { Watson }\end{array}$ \\
\hline \multicolumn{6}{|l|}{ Model 1} \\
\hline Hizmetkâr Liderlik (HL) & $0.307^{* *}$ & 0.092 & 0.094 & $45.491^{* *}$ & 2.096 \\
\hline \multicolumn{6}{|l|}{ Model 2} \\
\hline \multicolumn{6}{|l|}{ Hizmetkâr Liderlik (HL) } \\
\hline \multirow[t]{2}{*}{ Lidere Güven (LG) } & $0.168^{* *}$ & & & & \\
\hline & $0.464^{* *}$ & 0.287 & 0.196 & $120.881^{* *}$ & 2.146 \\
\hline \multicolumn{6}{|l|}{ Model 3} \\
\hline Etkileşim (HL* LG) & $0.472^{* *}$ & 0.221 & 0.223 & $125.683^{* *}$ & 2.112 \\
\hline
\end{tabular}

$\mathrm{n}=378,{ }^{* *} \mathrm{p}<0.01$, Standardize Beta Değerleri Kullanılmıştır. (Bağımlı Değişken: Örgütsel Vatandaşlık Davranı̧̧ (OVD))

Tablo 3. Lidere Güvenin Hizmetkâr Liderlik ve Çalışan Yaratıcılı̆̆ İlişkisindeki Düzenleyici Rolü

\begin{tabular}{|c|c|c|c|c|c|}
\hline & $\begin{array}{c}\text { Yaratıcilık } \\
(\beta)\end{array}$ & Düzeltilmiş $\mathrm{R}^{2}$ & $\Delta R^{2}$ & F Değişimi & $\begin{array}{l}\text { Durbin- } \\
\text { Watson }\end{array}$ \\
\hline \multicolumn{6}{|l|}{ Model 1} \\
\hline Hizmetkâr Liderlik (HL) & $0.312^{* *}$ & 0.095 & 0.097 & $47.208^{* *}$ & 1.748 \\
\hline
\end{tabular}

\section{Model 2}

Hizmetkâr Liderlik (HL)

Lidere Güven (LG) $\quad 0.209^{* *}$

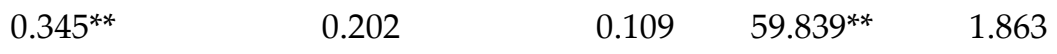

\section{Model 3}

Etkileşim $\left(\mathrm{HL}^{*} \mathrm{LG}\right)$

$0.417^{* *}$

0.172

$0.17492 .077^{* *}$

1.847

$\mathrm{n}=378,{ }^{* *} \mathrm{p}<0.01$, Standardize Beta Değerleri Kullanılmıştır. (Bağımlı Değişken: Çalışan Yaratıcılığı)

Yukarıda verilen tablo sonuçlarından da anlaşılacağı üzere hizmetkâr liderliğin örgütsel vatandaşlık davranışları $(\beta=0.307 ; p<0.01)$ ve çalışan yaratıcılığını $(\beta=0.312 ; p<0.01)$ pozitif olarak etkilediği tespit edilmiştir. Bu kapsamda H1: “Hizmetkâr liderlik davranışları çalışanların örgütsel vatandaşlık davranışlarını pozitif olarak etkilemektedir" ve H2:“Hizmetkâr liderlik davranışları çalışanların yaratıcılığını pozitif olarak etkilemektedir" hipotezlerinin kabul edildiğini ifade etmek mümkündür. Düzenleyici değişkenlere yönelik yapılan değerlendirmelerde de öncelikle Stone ve Hollenbeck (1989) tarafından önerilen ve düzenleyici etkinin anlamlılığını grafiksel olarak da ortaya koyan basit eğim testleri yapılmıştır. Bu yöntem neticesi elde edilen 
grafiksel gösterimler aşağıdaki grafikler olan Şekil-2 ve Şekil-3'de sunulmuştur. Bu sayede etkinin yüksek ve düşük düzeylerine göre de anlamlı olup olmadığı araştırılmıştır.

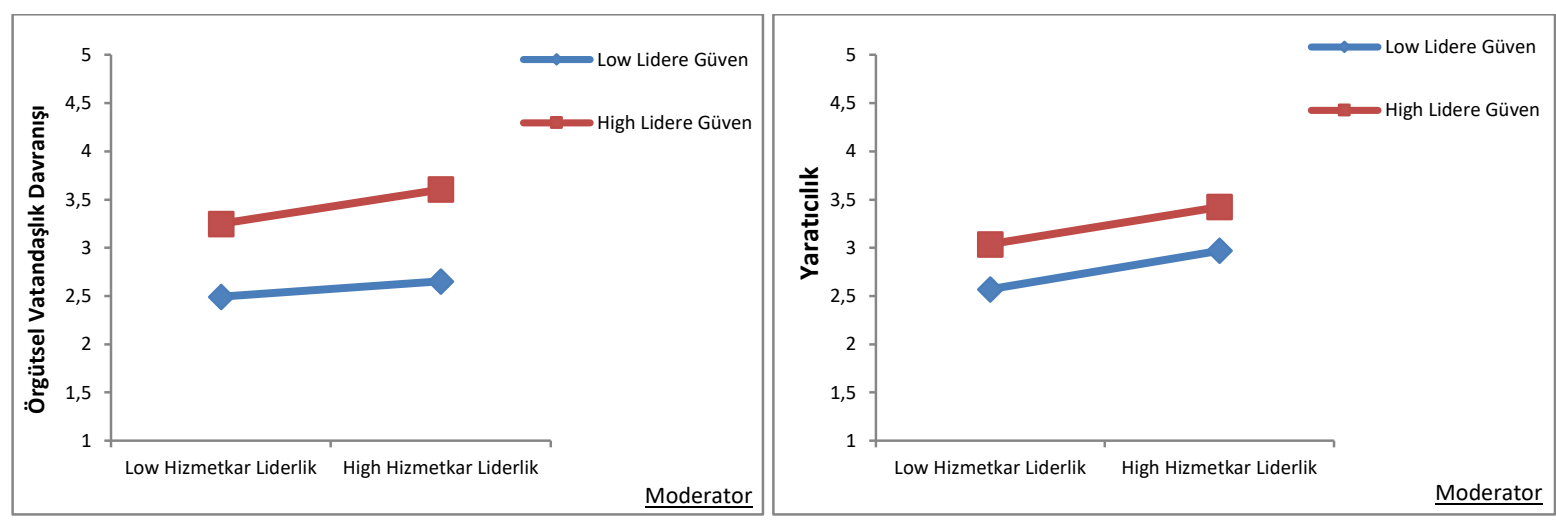

Şekil 2 ve Şekil 3. Eğim Testleri

Yukarıdaki tablo değerleri ve eğim testlerinden de anlaşılacağı üzere yüksek ve düşük düzey lidere güven seviyelerinde hizmetkâr liderliğin örgütsel vatandaşlık davranışı ve yaratıcllığa etkisinde etki sıfır değerini içermediğinden kurulan düzenleyici değişken hipotezlerimiz olan H3a: "Lidere olan güven hizmetkâr liderlik davranışları ve örgütsel vatandaşlık davranışları ilişkisinde düzenleyici role sahiptir. Bu ilişkide yüksek seviye lidere güven ilişkinin kuvvetini artıracaktır" ve H3b: "Lidere olan güven hizmetkâr liderlik davranışları ve çalışanların yaratıcılığı ilişkisinde düzenleyici role sahiptir. Bu ilişkide yüksek seviye lidere güven ilişkinin kuvvetini artıracaktır" hipotezleri de desteklenmiştir. Yani, lidere olan güven hizmetkâr liderliğin örgütsel vatandaşlık davranışları ve yaratıcılık ile olan ilişkilerinde düzenleyici role sahiptir. Ayrıca, yine grafik sonuçlarından da anlaşılacağı üzere lidere güven düzeyi arttıkça ilişkilerin kuvvetinin de arttığ1 tespit edilmiştir.

\section{Sonuç ve Öneriler}

Günümüz modern teknolojileri ile birlikte iş ve işgücü piyasasında olan büyük dönüşümler de işletmelerin sürdürülebilirlikleri adına çeşitli stratejiler geliştirmelerini zorunlu kılmaktadır. Karşılıklı ilişkilerin ve sosyal birlikteliklerin olduğu sosyal etkileşim alanında herkesin çıkar ve faydalarının doğruluk ve dürüstlük bakış açısı çerçevesinde maksimize edilmesi gerektiği, liderlik davranışlarını daha ön plana çıkarmaktadır (Akdogan ve Demirtas, 2014). Özellikle insan faktörünün artık daha önemli olduğu, insanların karşılıklı sosyal mübadele içerisinde bulunduğu ve sürekli bir sosyal etkileşimin olduğu alanlarda, mevcut ilişkilerin de çeşitli şekillerde en iyi yönetimsel uygulamalar ile yönetilmesi ve yönlendirilmesi gerekmektedir. İşte bu noktada karşımıza çıkan lider ve onun rol model olarak sergilediği davranışlar bireysel ve örgütsel çıktılar adına önemli bir girdiyi oluşturmaktadır (Demirtas, 2013).

Hizmetkâr liderlik kavramı da liderlerin takipçilerini etkileme ve yönlendirme sürecinde daha çok hizmet odaklı bir bakış açısı ile yönetimsel uygulamalarda bulunmalarını vurgulayan ve özellikle son yıllarda artan bir ilgi ile çeşitli bireysel ve örgütsel değişkenler ile ilişkileri araştırılan bir liderlik türüdür. Bu kapsamda mevcut çalışmamızda da hizmetkar liderlik davranışlarının örgüt üyelerinin pro-sosyal davranışları kapsamında ele alınan örgütsel vatandaşlık davranışları ile yaratıcılıklarına olan etkisi araştıılmıştır. İlave olarak da liderlerin önemli bir görevi olan ve örgüt içi ve dışındaki tüm faaliyetlerde paydaşların davranışlarında bir girdi sağlayan güven kavramı modele dahil edilmiştir. Bu kapsamda da güven düzeyinin hizmetkâr lider davranışlarının etkilerindeki düzenleyici rolü ele alınmıştır.

Çalışma sonuçları literatür bulguları ile benzer bir şekilde hizmetkar liderliğin örgütsel vatandaşlık davranışlarını (Ehrhart, 2004; Luu, 2019; Amah, 2018; Walumbwa vd., 2010; Vondey, 2010) ve çalışan yaratıcılığını (Williams vd., 2017; Yang vd. 2017; Yang vd., 2019) pozitif olarak etkilediğini ortaya koymuştur. Ayrıca, lidere olan güven düzeyinin de hem hizmetkar liderlik ile örgütsel vatandaşlık davranışı hem de çalışan yaratıcılığı ilişkilerinde aracı bir role sahip olduğu tespit edilmiştir. Bu sonuç Jaiswal ve Dhar (2017) tarafından da vurgulanan güven düzeyinin hizmetkâr lider ve yaratıcılık ilişkisindeki aracılık rolüne farklı bir kültürel bağlamdaki uygulamalı sonuçları ile destek vermektedir. 


\section{K. E. Yildırım 11/3 (2019) 2242-2256}

Hizmetkâr liderlik konusuna olan ilgi son yıllarda giderek artmaktadır. Bu konuda yazılan makale ve kitapların sayısı artmakta, bunlara ilave olarak Fortune dergisinin "Çalışmak İçin En iyi 100 şirket" listesinde yer alan işletmelerin pek çoğu hizmetkâr liderliği benimsemekte ve kurum kültürü ile bütünleştirmek için çalışmalar yapmaktadır (Spears, 2010: 29). Bu nedenle hizmetkâr liderlik ve hizmetkâr liderliğin örgütsel çıktılara etkisi konusunda yapılacak çalışmalar önem arz etmektedir. Dolayısı ile bu çalışmadan elde edilecek sonuçların örgütsel alandaki bilgi birikimine önemli katkılar sağlayacağı değerlendirilmektedir. İlave olarak Turan anlayışı çerçevesinde kenetlenen Türk Dünyası'nda da mevcut ülkünün gerçekleştirilmesinde önemli bir faktör olan liderlik uygulamaları ve etkileri kapsamında bir değerlendirme yapılmış olması ve uygulayıcılara mevcut durum analizi ve yorumlamalar sunması çalışmanın önemli diğer bir katkısıdır.

Gerek uygulamada gerekse literatürde çalışanların liderlik algılarını ölçen çeşitli ölçekler elbette bulunmaktadır. Dönüşümcü, etik, otantik vb. liderlik türlerinin ölçümleri yapılmaktadır. Ancak, hizmetkâr liderlik kavramı özellikle Türk Dünya Ülkeleri örgütsel davranış literatüründe henüz yeni bir uygulama alanıdır. Bu nedenle mevcut çalışma ile henüz başlangıç safhasında olan Türkçe literatüre önemli bir kazanım sağlandığı değerlendirilmektedir. Ayrıca, bu yeni uygulama alanının mevcut çalışma ile hem literatür altyapısı hem de uygulamalı olarak sonuçlarının yorumlanmasının hem akademik hem de uygulamada olan liderlere önemli kazanımlar sağlayacağı düşünülmektedir.

Çalışma mevcut katkıları yanı sıra uygulamalı araştırma sürecindeki bulgularını örneklem grubu itibariyle tek bir kültüre ait sonuçlar çerçevesinde yorumlamaktadır. Bu da neticede bir kısıtlılık oluşturmakta ve yeni çalışmalar ile farklı kültürlerde de sonuçların araştırılmasını ve bu sayede genellenebileceğini işaret etmektedir. Ayrıca, çalışmada ortak yöntem hatası da potansiyel bir kısıt olarak bulunmaktadır. Bu kapsamda gelecek çalışmalar için de verilerin zamana dayalı toplanması önerilmektedir. Ayrıca, hizmetkar liderlik literatürüne katkı sağlama adına yeni çalışmalarda farklı örgütsel davranış değişkenlerinin de ele alınması önerilmektedir.

Sonuç olarak bu çalışmada; hizmetkâr liderlik davranışlarının örgütsel vatandaşlık davranışları ve çalışan yaratıcılığı üzerinde pozitif etkide bulunduğu ve öne sürülen etki sürecinde lidere olan güven düzeyinin de aracı bir role sahip olduğu tespit edilmiştir

\section{KAYNAKÇA}

Aiken, L. S., West, S. G., \& Reno, R. R. (1991). Multiple regression: Testing and interpreting interactions. Sage.

Akdogan, A. A., \& Demirtas, O. (2014). Managerial role in strategic supply chain management. Procedia-Social and Behavioral Sciences, 150, 1020-1029.

Akdoğan, A., \& Demirtaş, Ö. (2014). Etik liderlik davranışlarının etik iklim üzerindeki etkisi: örgütsel politik algılamaların aracı rolü.

Amah, O. E. (2018). Determining the antecedents and outcomes of servant leadership. Journal of General Management, 43(3), 126-138.

Arnold, K. A., Barling, J., \& Kevin Kelloway, E. (2001). Transformational leadership or the iron cage: which predicts trust, commitment and team efficacy?. Leadership \& Organization Development Journal, 22(7), 315320.

Bandura, A. (1986). Social foundations of thought and action. Englewood Cliffs, NJ, 1986.

Bateman, T. S., \& Organ, D. W. (1983). Job satisfaction and the good soldier: The relationship between affect and employee "citizenship". Academy of management Journal, 26(4), 587-595.

Bennis, W. (2002). Become a tomorrow leader. Focus on leadership: Servant-leadership for the 21st century, 101109.

Bissola, R., \& Imperatori, B. (2011). Organizing individual and collective creativity: Flying in the face of creativity clichés. Creativity and Innovation Management, 20(2), 77-89.

Blau, P. (1964). Power and exchange in social life. New York: J Wiley \& Sons, 352. 


\section{K. E. Yildırım 11/3 (2019) 2242-2256}

Brower, H. H., Schoorman, F. D., \& Tan, H. H. (2000). A model of relational leadership: The integration of trust and leader-member exchange. The Leadership Quarterly, 11(2), 227-250.

Demirtaş, Ö. (2013). Havacılık Endüstrisinde Stratejik Yönetim: SWOT Analizi ile Durum Değerlendirmesi. Nevşehir Hacı Bektaş Veli Üniversitesi SBE Dergisi, 2(2), 207-238

Demirtaş, Ö., \& Biçkes, D. M. (2014). Makyavelizm'in olumsuz durumları ifşa etme niyeti üzerindeki etkisi: Bir alan çalışması. ISGUC The Journal of Industrial Relations and Human Resources, 16(2), 96-112.

De Pree, M. (2002). „Servant-leadership: Three things necessary“. Focus on leadership: Servant leadership for the, 21, 89-100.

Dirks, K. T., \& Ferrin, D. L. (2002). Trust in leadership: meta-analytic findings and implications for research and practice. Journal of applied psychology, 87(4), 611.

Ehrhart, M. G. (2004). Leadership and procedural justice climate as antecedents of unit-level organizational citizenship behavior. Personnel psychology, 57(1), 61-94.

Eren, Erol (2003), Yönetim ve Organizasyon, 6. Baskı, Beta Yayınları, İstanbul.

Farh, L. L., Zhong, C.-B., \& Organ, D. W. (2004). Organizational Citizenship Behavior in the People's Republic of China. Organization Science, 15(2), 241.

Gibson, J. L., Ivancevich, J. M., Donnelly, J. H., \& Konopaske, R. (2003). Organizations: Behavior, Structure, Process. 11th eds.

Gong, Y., Zhou, J., \& Chang, S. (2013). Core knowledge employee creativity and firm performance: The moderating role of riskiness orientation, firm size, and realized absorptive capacity. Personnel Psychology, 66(2), 443-482.

Greenleaf, R. K. (1977). Servant leadership: A journey into the nature of legitimate power and greatness. New York: Paulist Press.

Greenleaf, R. K. (1998). The power of servant-leadership: Essays. Berrett-Koehler Publishers.

Greenleaf, R. K. (2008). The servant as leader. Greenleaf Center for Servant Leadership.

Gupta, N., Jang, Y., Mednick, S. C., \& Huber, D. E. (2012). The road not taken: Creative solutions require avoidance of high-frequency responses. Psychological Science, 23(3), 288-294.

Hirak, R., Peng, A. C., Carmeli, A., \& Schaubroeck, J. M. (2012). Linking leader inclusiveness to work unit performance: The importance of psychological safety and learning from failures. The Leadership Quarterly, 23(1), 107-117.

Hurt, H. T., Joseph, K., \& Cook, C. D. (1977). Scales for the measurement of innovativeness. Human Communication Research, 4, 58-65.

Jaiswal, N. K., \& Dhar, R. L. (2017). The influence of servant leadership, trust in leader and thriving on employee creativity. Leadership \& Organization Development Journal, 38(1), 2-21.

Joseph, E. E., \& Winston, B. E. (2005). A correlation of servant leadership, leader trust, and organizational trust. Leadership \& Organization Development Journal, 26(1), 6-22.

Jung, D. I., Chow, C., \& Wu, A. (2003). The role of transformational leadership in enhancing organizational innovation: Hypotheses and some preliminary findings. The leadership quarterly, 14(4-5), 525-544.

Liden, R. C., Wayne, S. J., Zhao, H., \& Henderson, D. (2008). Servant leadership: Development of a multidimensional measure and multi-level assessment. The leadership quarterly, 19(2), 161-177.

Lievens, F., \& Anseel, F. (2004). Confirmatory factor analysis and invariance of an organizational citizenship behaviour measure across samples in a Dutch-speaking context. Journal of Occupational and Organizational Psychology, 77(3), 299-306. 


\section{K. E. Yildırım 11/3 (2019) 2242-2256}

Luu, T. T. (2019). Building employees' organizational citizenship behavior for the environment: The role of environmentally-specific servant leadership and a moderated mediation mechanism. International Journal of Contemporary Hospitality Management, 31(1), 406-426.

Mayer, J. D., Roberts, R. D., \& Barsade, S. G. (2008). Human abilities: Emotional intelligence. Annu. Rev. Psychol., 59, 507-536.

Nakip, M. (2003). Pazarlama Araştırma Teknikler ve (SPSS Destekli) Uygulamalar. 1. Baskı. Ankara: Seçkin Yayıncilik.

Neubert, M. J., Hunter, E. M., \& Tolentino, R. C. (2016). A servant leader and their stakeholders: When does organizational structure enhance a leader's influence?. The Leadership Quarterly, 27(6), 896-910.

Neubert, M. J., Kacmar, K. M., Carlson, D. S., Chonko, L. B., \& Roberts, J. A. (2008). Regulatory focus as a mediator of the influence of initiating structure and servant leadership on employee behavior. Journal of applied psychology, 93(6), 1220.

Oldham, G. R., \& Cummings, A. (1996). Employee creativity: Personal and contextual factors at work. Academy of management journal, 39(3), 607-634.

Ole Borgen, S. (2001). Identification as a trust-generating mechanism in cooperatives. Annals of public and cooperative economics, 72(2), 209-228.

Organ, D. W. (1988). Organizational citizenship behavior: The Good Soldier Syndrome, Lexington, MA: Lexington Books.

Organ, D. W., \& Ryan, K. (1995). A Meta-analytic Review of Attitudinal and Dispositional Predictors of Organizational Citizenship Behavior. Personnel Psychology, 48(4), 775.

Özdaşl1, K., \& Yücel, S. (2010). Yöneticiye Bağlılıkta Yöneticiye Güvenin Etkisi: Yapısal Eşitlik Modeli İle Bir Analiz. Süleyman Demirel Üniversitesi Sosyal Bilimler Enstitüsü Dergisi, 11, 67-83.

Özkalp, E., \& Kırel, Ç. (2004). Örgütsel Davranış, Eskişehir: Anadolu Üniversitesi Yayınları, 2.Baskı

Page, D., \& Wong, P. T. (2000). “A conceptual framework for measuring servant leadership". S. Adjibolosoo (Ed.), The human factor in shaping the course of history and development. Boston: University Press of America.

Paine, J. B., \& Organ, D. W. (2000). The Cultural Matrix of Organizational Citizenship Behavior: Some Preliminary Conceptual and Empirical Observations. Human Resource Management Review, 10(1), 45-59

Patterson, K. A. (2003). Servant leadership: A theoretical model. Servant Leadership Roundtable. Regent University School of Leadership Studies. Virginia Beach, VA.

Penner, L. A., Midili, A. R., \& Kegelmeyer, J. (1997). Beyond job attitudes: A personality and social psychology perspective on the causes of organizational citizenship behavior. Human Performance, 10(2), 111-131.

Podsakoff, N. P., Whiting, S. W., Podsakoff, P. M., \& Blume, B. D. (2009). Individual- and Organizational-Level Consequences of Organizational Citizenship Behaviors: A Meta-Analysis. Journal of Applied Psychology, 94(1), 122-141. doi: 10.1037/a0013079

Podsakoff, N. P., Whiting, S. W., Podsakoff, P. M., \& Blume, B. D. (2009). Individual- and Organizational-Level Consequences of Organizational Citizenship Behaviors: A Meta-Analysis. Journal of Applied Psychology, 94(1), 122-141. doi: 10.1037/a0013079

Podsakoff, P. M., \& MacKenzie, S. B. (1997). Impact of organizational citizenship behavior on organizational performance: A review and suggestion for future research. Human performance, 10(2), 133-151.

Podsakoff, P. M., Ahearne, M., \& MacKenzie, S. B. (1997). Organizational citizenship behavior and the quantity and quality of work group performance. Journal of applied psychology, 82(2), 262.

Podsakoff, P. M., MacKenzie, S. B., \& Podsakoff, N. P. (2012). Sources of method bias in social science research and recommendations on how to control it. Annual review of psychology, 63, 539-569. 


\section{K. E. Yildırım 11/3 (2019) 2242-2256}

Podsakoff, P. M., MacKenzie, S. B., Moorman, R. H., \& Fetter, R. (1990). Transformational leader behaviors and their effects on followers' trust in leader, satisfaction, and organizational citizenship behaviors. The leadership quarterly, 1(2), 107-142.

Podsakoff, P. M., MacKenzie, S. B., Paine, J. B., \& Bachrach, D. G. (2000). Organizational Citizenship Behaviors: A Critical Review of the Theoretical and Empirical Literature and Suggestions for Future Research. Journal of Management, 26(3), 513-563.

Posner, B. Z., \& Kouzes, J. M. (1993). Psychometric properties of the leadership practices inventoryupdated. Educational and psychological measurement, 53(1), 191-199.

Rawlinson, J. G. (2017). Creative thinking and brainstorming. Routledge.

Reinke, S. J. (2004). Service before self: Towards a theory of servant leadership. Global Virtue Ethics Review, 5(3), 30-57.

Robbins, S. P., \& Judge, T. A. (2001). Organizational behavior. Pearson

Rousseau, D. M., Sitkin, S. B., Burt, R. S., \& Camerer, C. (1998). Not so different after all: A cross-discipline view of trust. Academy of management review, 23(3), 393-404.

Russell, R. F., \& Gregory Stone, A. (2002). A review of servant leadership attributes: Developing a practical model. Leadership E Organization Development Journal, 23(3), 145-157.

Sani, Ü., Çalışkan, S. C., Atan, Ö., \& Yozgat, U. (2013). Öğretim Üyelerinin Hizmetkâr Liderlik Davranışları ve Ardılları Üzerine Bir Araştırma. Ege Academic Review, 13(1), 63-82

Sarkus, D. J. (1996). Servant-leadership in safety: Advancing the cause and practice. Professional Safety, 41(6), 26.

Shalley, C. E., \& Gilson, L. L. (2004). What leaders need to know: A review of social and contextual factors that can foster or hinder creativity. The leadership quarterly, 15(1), 33-53.

Shaw, R. B. (1997). Trust in the balance: Building successful organizations on results, integrity, and concern. San Francisco, CA: Jossey-Bass.

Spears, L. (1996). Reflections on Robert K. Greenleaf and servant-leadership. Leadership E organization development journal, 17(7), 33-35.

Spears, L. C. (2010). On character and servant-leadership: Ten characteristics of effective, caring leaders. The Journal of Virtues E Leadership, 1(1), 25-30.

Spears, L.C. (1995), Reflections on Leadership: How Robert K. Greenleaf's Theory of Servant-Leadership Influenced Today's Management Thinkers, Wiley, New York.

Stone, E. F., \& Hollenbeck, J. R. (1989). Clarifying some controversial issues surrounding statistical procedures for detecting moderator variables: Empirical evidence and related matters. Journal of Applied Psychology, 74(1), 3.

Sungur, N. (1997). Yaratıcı düşünce. Evrim Yayınevi.

Tan, H. H., \& Tan, C. S. (2000). Toward the differentiation of trust in supervisor and trust in organization. Genetic, Social, and General Psychology Monographs, 126(2), 241.

Tierney, P., Farmer, S. M., \& Graen, G. B. (1999). An examination of leadership and employee creativity: The relevance of traits and relationships.Personnel Psychology, 52(3), 591-620.

Van Dierendonck, D. (2011). Servant leadership: A review and synthesis.Journal of Management, 37(4), 12281261.

Van Dyne, L., Graham, J. W., \& Dienesch, R. M. (1994). Organizational citizenship behavior: Construct redefinition, measurement, and validation. Academy of management Journal, 37(4), 765-802.

Vinod, S., \& Sudhakar, B. (2011), “Servant Leadership: A Unique Art of Leadership!” Interdisciplinary Journal of Contemporary Research in Business, 2(11), 456-467. 


\section{K. E. Y1ldirım 11/3 (2019) 2242-2256}

Vondey, M. (2010). The relationships among servant leadership, organizational citizenship behavior, personorganization fit, and organizational identification.International Journal of Leadership Studies, 6(1), 3-27.

Walumbwa, F. O., Hartnell, C. A., \& Oke, A. (2010). Servant leadership, procedural justice climate, service climate, employee attitudes, and organizational citizenship behavior: a cross-level investigation. Journal of Applied Psychology, 95(3), 517.

Wang, P., Rode, J. C., Shi, K., Luo, Z., \& Chen, W. (2013). A workgroup climate perspective on the relationships among transformational leadership, workgroup diversity, and employee creativity. Group $\mathcal{E}$ Organization Management, 38(3), 334-360.

Wilkes, R. (2011). Re-thinking the decline in trust: A comparison of black and white Americans. Social Science Research, 40(6), 1596-1610.

Williams Jr, W. A., Brandon, R. S., Hayek, M., Haden, S. P., \& Atinc, G. (2017). Servant leadership and followership creativity: The influence of workplace spirituality and political skill. Leadership $\mathcal{E}$ Organization Development Journal, 38(2), 178-193.

Yang, J., Gu, J., \& Liu, H. (2019). Servant leadership and employee creativity: The roles of psychological empowerment and work-family conflict. Current Psychology, 1-11.

Yang, J., Liu, H., \& Gu, J. (2017). A multi-level study of servant leadership on creativity: The roles of selfefficacy and power distance. Leadership \& Organization Development Journal, 38(5), 610-629.

Zhang, X., \& Bartol, K. M. (2010). Linking empowering leadership and employee creativity: The influence of psychological empowerment, intrinsic motivation, and creative process engagement. Academy of management journal, 53(1), 107-128. 